\title{
ミニシンポジウム 二酸化炭素の海洋隔離技術と生物への影響
}

\section{III-3. 魚類成体への影響}

\author{
石松 惊, ${ }^{1}$ 林 正 裕, ${ }^{1}$ 喜田 潤 2 \\ 1長崎大学水産学部附属海洋資源教育研究センター, 2 海洋生物環境研究所
}

III-3. Effects on Adult Fish

Atsushi Ishimatsu, ${ }^{1}$ Masahiro Hayashi, ${ }^{1}$ Jun $\mathrm{Kita}^{2}$

\begin{abstract}
${ }^{1}$ Marine Research Institute, Faculty of Fisheries, Nagasaki University, 1551-7 Tairamachi, Nagasaki 851-2123, ${ }^{2}$ Marine Ecology Research Institute, Onjuku, Chiba 299-5105, Japan
\end{abstract}

魚類は水中に乏しい $\mathrm{O}_{2}$ を効率よく得るため, 酸素摂 取能力が高い鰓を発達させている。鰓表面では, 口から 鰓孔へと流れる水が逆行する血液の流れと, 僅か数ミク ロンの上皮を介して接しており，非常に効率の高いガス 交換が営まれている。 $\mathrm{O}_{2}$ と比較すると分子状 $\mathrm{CO}_{2}$ は水 に対する溶解度が約 30 倍も大きく, 従って, 魚類は $\mathrm{CO}_{2}$ 排出に関しては過呼吸の状態にある。その結果, 魚類体液の $\mathrm{CO}_{2}$ 分压 $\left(P \mathrm{CO}_{2}\right)$ は $0.27 \sim 0.54 \mathrm{kPa}(1 \mathrm{kPa}$ $=7.5 \mathrm{mmHg}$ ） と, 陸上生物の体液 $P \mathrm{CO}_{2}$ と比べると 1 桁低くなっている。従って, 水中 $P \mathrm{Co}_{2}$ の僅かの上昇も 鰓を介しての $\mathrm{PCO}_{2}$ 勾配を逆転させ, 体液 $\mathrm{PCO}_{2}$ を増加さ せる可能性がある。鰓を通って体液中に急速に拡散した $\mathrm{CO}_{2}$ は, $\mathrm{H}_{2} \mathrm{CO}_{3} \rightarrow \mathrm{HCO}_{3}^{-} \rightarrow \mathrm{CO}_{3}^{2-}$ 一と解離し, 体液 $\mathrm{pH}$ を低下させることによって生体に様々な生理的影響を与 える。1)

$\mathrm{CO}_{2}$ が魚類に与える影響については，現在までほと んどが淡水産の種で調べられており, 海産魚類について の知見は極めて限られている。2001 年 3 月の時点で, $\mathrm{CO}_{2}$ が魚類に与える影響について文献検索を行って得 られた総文献数 99 編の中, 淡水魚を用いた研究が全体 の 4 分の 3 を超える 79 編を占め, 海産魚では軟骨魚類 を用いた研究が 10 編, 海産真骨魚類を用いた研究は 9 編に止まった。実験期間に関しては, 海産魚に限って見 ると最長の実験期間でも 120 時間に止まっていた。

\section{1. 急性毒性}

$\mathrm{CO}_{2}$ を $5 \%$ 以上含む空気で平衡させた海水中では, 短時間の中に海産の真骨魚類は敬死する（林・Cuéllar ・石松 未発表)。ヒラメでは, $4 \% \mathrm{CO}_{2}$ に平衡させた 海水中（ $\left(\mathrm{PCO}_{2}=4 \mathrm{kPa}\right)$ では 72 時間まで整死率 $0 \%$ で あったが， $5 \%$ では 48 時間以内に全個体 $(\mathrm{N}=5)$ が整 死した。ブリでは, 整死時間はより短く, $5 \% \mathrm{CO}_{2}$ に平 衡させた海水中で 8 時間以内に全個体の整死が起こっ だ。ーロッパの海産 seabass (Dicentrarchus labrax) で, 96 時間及び 120 時間 $\mathrm{LC}_{50}$ はそれぞれ $\mathrm{PCO}_{2} \quad 6.72 \mathrm{kPa}$,

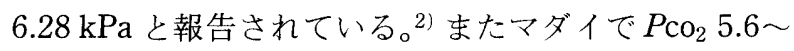

$6.0 \mathrm{kPa}$ で 22 時間整死率 $40 \%$ ，これ以上では全個体が 死亡したとの報告がある。

\section{2. 血液酸素運搬能}

$\mathrm{PCO}_{2}$ の上昇に伴ってへモグロビンの酸素親和性は生 理的 $\mathrm{pH}$ の範囲内では低下する。この効果は軟骨魚類を 除く沗椎動物一般の血液に関して認められ, Bohr 効果 と呼ばれる。これに加えて, 真骨魚類では $\mathrm{PCO}_{2}$ の増加 は酸素容量をも低下させる (Root 効果)。高 $\mathrm{CO}_{2}$ 環境 下ではこれらの効果のために，へモグロビンと酸素との 結合が抑制される。真骨魚を高 $\mathrm{CO}_{2}$ 環境に移行させた 時, 血液 $P \mathrm{Co}_{2}$ の上界による $\mathrm{pH}$ の低下が抢き, 動脈血 の酸素飽和度がいったん低下することがある。このよう な条件の下では頭腎クロム親和性細胞から血液中にカテ コルアミンが放出される。カテコルアミンは, 赤血球膜 表面に存在する $\beta$ 受容体に作用して膜の $\mathrm{Na}^{+} / \mathrm{H}^{+}$ポン プを活性化させ，へモグロビンの酸素飽和度を回復させ るように働く。また血中カテコルアミン濃度の上昇は脾 蔵からの赤血球の放出を促し，ヘマトクリットを増大さ せる。4)

\section{3. 呼吸運動}

一般に魚類を含む水生動物の換水運動は, 酸素の摂取 を主要な調節因子として機能しているといわれ， $\mathrm{CO}_{2}$ の排出が換気の主な調節因子となっている空気呼吸動物 に打ける換気調節機構と対比されてきた。しかし，最 近 $\mathrm{CO}_{2}$ の呼吸刺激因子としての重要性を示唆する実験 結果が報告されるようになり，従来の見解の見直しが迫 られている。

\section{4. 酸塩基平衡}

高 $\mathrm{CO}_{2}$ 環境に曝露された場合の魚類の血液 $\mathrm{pH}$ は, 急速なしかし一過性の低下とそれに続く正常 $\mathrm{pH} へ$ の回 復が特徵である。この時, 血液の $\mathrm{HCO}_{3}^{-}$は時間ととも に負荷された $\mathrm{CO}_{2}$ レベルに応じて上昇する（図 $1 \mathrm{~A}$ )。 酸性水に曝露された場合の応答は，これとは異なり曝露 初期の急速な低下と回復は見られない（図 1B)。

$\mathrm{CO}_{2}$ レベルの上昇によって引き起こされる体液 $\mathrm{pH}$ の 
(A)

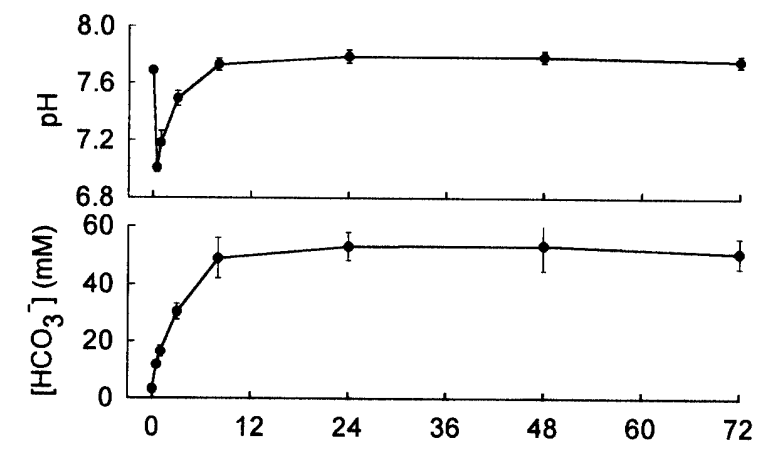

(B)

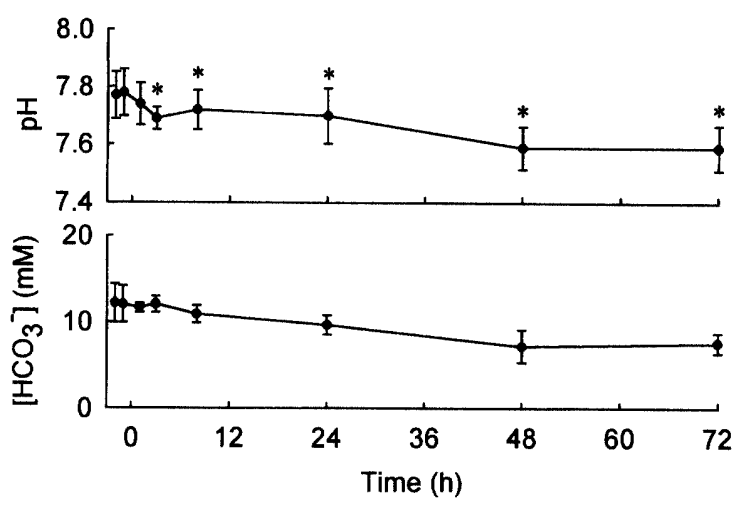

図 $1 \mathrm{CO}_{2}$ 及び酸性水曝露時の血液 $\mathrm{pH}$ と血漿 $\mathrm{HCO}_{3}^{-}$人 オン濃度の変化。(A) ヒラメ: $3 \% \mathrm{CO}_{2}$ 曝露, 水温 20 ${ }^{\circ} \mathrm{C}$ (林・石松 未発表)，(B) ウナギ : 酸性水 $\mathrm{pH} 4.5$, 水温 $20^{\circ} \mathrm{C}$ (石松・田川 未発表)。

低下（呼吸性アシドーシス）に対する補償は，水中動物 の場合, 主に環境水中への酸排出によって行われる。 $\mathrm{CO}_{2}$ 曝露開始直後の血液 $\mathrm{pH}$ の低下幅は, 同時に起こる 環境水の $\mathrm{pH}$ 低下の幅よりもかなり小さく保たれる（1
$\% \mathrm{CO}_{2}$ 条件下で，海水 $\mathrm{pH}$ は 8.2 から 7.0 一低下するの に対し, 血液 $\mathrm{pH}$ の低下幅はヒラメで 0.15 , ブリで 0.09 (林・Cuéllar - 石松 未発表) )。 $\mathrm{CO}_{2}$ 曝露時の $\mathrm{pH}$ 回復速度は海産魚で早く, 淡水魚では遅い。魚類では鰓 が主な排出器官であり, 腎臟の寄与は一般に僅かであ る。環境水 $P \mathrm{Co}_{2}$ が $1 \sim 2 \mathrm{kPa}$ の場合, 淡水魚・海産魚 を問わず血液 $\mathrm{pH}$ の回復時に, ほほ $1: 1$ のモル比で血 液 $\mathrm{HCO}_{3}^{-}$濃度の上昇に伴う $\mathrm{Cl}^{-}$濃度の低下が起こる。 しかし，ヒラメ及びブリを用いた実験では， $\mathrm{CO}_{2}$ レベ ルがより高くなると血液 $\mathrm{Na}^{+}$濃度が顕著に上昇する結 果が得られた。をた血液 $\mathrm{pH}$ が回復した後に, 実験魚の 整死が起きており, 死因として血液 $\mathrm{pH}$ 以外が重要だと 思われる (林・Cuéllar・石松, 未発表)。

\section{5. 今後の研究課題}

高 $\mathrm{CO}_{2}$ 環境下での死因を解明すると共に，長期曝露 試験による成熟, 内分泌など広範な生理機能に対する影 響調查を行う必要がある。高 $\mathrm{CO}_{2}$ 環境下での生理反応 は, 酸性水に対する反応と全く異なっており,この点に 留意して研究を進めるべきである。

\section{文献}

1）石松 毫, 喜田 潤. $\mathrm{CO}_{2}$ が魚類に与える影響について. 魚類学雑誌 $1999 ; 46: 1-13$.

2) Grottum JA, Sigholt T. Acute toxicity of carbon dioxide on European seabass (Dicentrarchus labrax) : Mortality and effects on plasma ions. Comp. Biochem. Physiol. 1996; 115A: 323-327.

3）竹田達右, 板沢靖男. 二酸化炭素麻䣷の活魚輸送への応用 可能性の検討. 日水誌 1983; 49: 725-731.

4) Nikinmaa M, Salana A. Oxygen transport in fish. In: Perry SF, Tufts B. (eds) Fish Respiration, Academic Press, San Diego, 1998; 141-184.

5）石松 惊. 「魚類生理学」恒星社厚生閣, 東京, 1991; 3565. 